\title{
The Paganism of the Ancient Prussians.
}

\section{Fred. C. Conybeare M.A.}

To cite this article: Fred. C. Conybeare M.A. (1901) The Paganism of the Ancient Prussians., Folklore, 12:3, 293-302, DOI: 10.1080/0015587X.1901.9719635

To link to this article: http://dx.doi.org/10.1080/0015587X.1901.9719635

$$
\text { 曲 Published online: } 06 \text { Feb } 2012 .
$$

Submit your article to this journal $\square$

\section{Џlll Article views: 3}

Q View related articles $\sqsubset$ 
Games, i., 126, but the last part was called " Driving Pigs to Market."

The playplace is generally mentioned as the doorstep or the hearthstone.

Some account of the classical game will be found in Traditional Games, i., 239, s.v. "Hucklebones," and references to the several British variants recorded by Mrs. Gomme have already been given, ante, p. 106.

14. The game is known in Persia, where, says my inform. mant, it is played by boys of the lower classes. - E. C. Sxres.

\section{THE PAGANISM OF THE ANCIENT PRUSSIANS.}

TRANSLATED BY FRED. C. CONYBEARE, M.A.

THERE was printed at Spiers (Spir $x$ ) in the year 1582 by Barnardus D'Albinus a volume, now become infinitely rare, of which the contents are thus described on the title page: "About the religion, sacrifices, wedding and funeral rites of the Russians, Moscovites, and Tartars, by various authors." Mr. Arthur Evans possesses a copy, which he has kindly lent to me. All the pieces are in Latin, and the first is a long controversial dialogue in which are discussed the respective merits of the new Lutheran religion and the faith of Muscovy. The discussion was held in Moscow early in the year 1570 , and no less a personage than Ivan the Terrible is put forward to assail the Lutheran faith, which is defended by the minister of Christ, John Rohita. Many cruelties perpetrated by the Muscovite tyrant against Lutherans are detailed in the course of the dialogue, and serve to dispel the opinion one often hears expressed, that the history of the Russian State has never, like that of other countries, been sullied by purely religious persecutions.

The gem of the collection,' however, is the tract about 


\section{The Paganism of the Ancient Prussians.}

the superstitions of the Borussi or Prussians, which fills pp. 257-264. It is so little known, that I have thought it worthy to be translated. It was written about 1553 , and affords us a pleasing picture of the old paganism of Prussia, which in that age still survived, hardly touched, in remote country places. The Borussi or Prussians were, of course, Slavs by race and akin to the Rutheni.-F. C. C.

\section{About the Religion and Sacrifices of the Ancient Prussians.}

\section{An Epistle of Fohn Meletius to George Sabine.}

My son Jerome, who is usually very much delighted with your writings, gave me to read that elegy of yours which you wrote to the Cardinal Peter Bembo, and in which you mention the custom of sacrificing a goat and of worshipping snakes found among some of the Sarmatian races. I could not help writing to you details I have ascertained of the vain cults of those peoples. Indeed, I expect you will not be sorry to understand more fully the customs and idolatry of tribes among which a certain destiny has summoned you, and in the neighbourhood of which you are passing your life. For many superstitious rites and idolatrous cults are still kept up in these regions, which as a fresh-comer you may not yet have learned about. This is why I have made up my mind to communicate to you whatever I have found out about them.

Not to trouble you with a longer preface, I will begin. by describing the sacrifices with which formerly the Borussi, Samogitæ, Lithuanians, Ruthenians, and Livonians worshipped the demons as if they were gods, and still continue to do so in secret in many places. Then I will describe

1 Meletius was arch-presbyter of the Ecclesia Liccensis in Prussia. Sabinus was a poet. Johannes Lasicius (Lasitzki), in his tract De diis Samagitarum, (Basil, 1615), reproduces the book of Meletius. It was reprinted by Michael Neander, Orbis terra Succincta Explicatio (Lipsix, 1597), p. 573 foll., and in this century by Ilaupt, vol. i., p. 146 foll. 


\section{The Paganism of the Ancient Prussians. 295}

certain superstitious rites usual among the same races in celebrating weddings, funerals, and wakes.

On St. George's. Day they are accustomed to offer a sacrifice to Pergrubrius, who is believed to be the god of flowers, plants, and of all seeds. This is how they sacrifice to Pergrubrius. The sacrificing priest, whom they call Vurschayten, holds in his right hand a dish (obda) full of beer, and after he has invoked the demon's name, chants his praises. "Thou," he says, "drivest away the winter; thou bringest back the pleasures of spring; through thee the fields and gardens grow green; through thee the woods and groves get their leaves." When he has finished this hymn, he takes the dish in his teeth, and drinks down the beer without touching it with his hand; then he throws backwards over his head the dish which he has drunk up, touching it only with his teeth. Next the dish is picked up off the ground and filled afresh, and all present drink out of it in order and sing a hymn in praise of Pergrubrius. After that they feast the whole day long and dance.

Similarly when the crops are ripe the rustics meet together in the fields for sacrifice, which in the Ruthenian tongue is called Zazinck, that is the beginning of spring. When this rite is finished one of their number is chosen and takes'a forecast or augury of the harvest by cutting down an armful of corn, which he carries home. On the morrow all, first the members of his household, then of the rest all who will, get in the harvest.

When, however, that is done they, offer up a solemn sacrifice by way of giving thanks. . This is called in the Ruthenian language Ozink, that is to say the completion of the harvest. In this sacrifice the Sudine peoples of Prussia, among whom amber is collected, sacrifice a goat, as you write in your elegy to Bembo.

The ritual of this sacrifice, however, is as follows. The people congregate together in a barn, and a goat is brought forward, which the Vursichaytes (sic), or sacrificer, is to slay. 


\section{The Paganism of the Ancient Prussians.}

He lays both hands on the victim and invokes in order the demons whom they believe to be gods, to wit: Occopirn, the god of heaven and earth; Antrimp, the god of the sea; Gardoaet, the god of sailors, such as of old among the Romans was Portunnus; Potrymp, the god of rivers and springs; Piluit, the god of riches, whom the Latins called Plutus; Pergrubrius, the god of spring; Pargn, the god of thunder and tempests; Poccl, the god of hell and of darkness; Poccoll, the god of the spirits of the air; Putscaet, the god that protects the sacred groves; the god Ausceut, of health and sickness; Marcoppol, the god of magnates and nobles; the Barstucca, whom the Germans call Erdmenlen, that is to say, the subterranean ones.

When the demons have been invoked, those who are present in the barn raise aloft, all together, the goat, and hold it up over their heads while a hymn is sung. When that is finished they put it down again to stand on the ground. Then the sacrificer admonishes the people to conduct this solemn sacrifice, instituted by the piety of their ancestors, with the most entire veneration, and to treasure up religiously the memory of it for their posterity. When he has delivered himself of this little homily to the people, he himself slays the victim and sprinkles about the blood, which has been caught in a patin. The flesh, howover, he hands over to the women in the barn in question for them to cook. They meantime, while the flesh is being cooked, get ready cakes of siligineous flour. These they do not put into the oven, but the men stand round the fire and turn them over and over in the fire without ceasing until they grow hard and are cooked. All this discharged, they feast and carouse all day and night, drinking till they vomit. Then the drunkards, at the top of the morning, go forth outside the village, where they choose a spot, and cover up with earth whatever is left over and remains of their feast, so that it may not become the prey either of 


\section{The Paganism of the Ancient Prussians. 297}

birds or of wild beasts. After that they dismiss the gathering, and each returns to his home.

For the rest, out of all the tribes of Sarmatia above mentioned, many. still worship with particular veneration Putscaet, who presides over trees and groves. $\mathrm{He}$ is believed to have his dwelling under the tree Sambuc. Men everywhere in their superstition make him offerings of bread, beer, and other sorts of food, which they lay under the Sambuc tree, praying of Putscaet that he will appease and make friendly to them Marcoppol, the god of magnates and nobles, to the end that their lords may not oppress them and make their servitude heavier to bear. They also pray that the Barstuccæ may be sent to them, which are, as I said before, called the underground spirits. For if the latter are tenanting the house, they believe that the owners are in good luck, and they place at eventide for them in the barn, on a table spread with a cloth, bread, cheese, butter, and beer. Nor do they doubt that it will bring them good luck, if next morning they find the food left there taken away. But if it" ever remains untouched on the table, they are in great distress and fearful of some calamity.

The same people worship certain spirits that can be seen with the eye, and which are called in Ruthenian Colfy, in Greek Coboli, in German Cobolds. , These spirits they believe to dwell in hidden places in their houses or in the network of the timbers; and they feed them handsomely on all sorts of 'food, because they are wont to bring to them who so feed them wheat which they have carried off by stealth from other men's stores.

When, however, these spirits desire to take up their residence and be fed somewhere or other, this is how they make known their disposition towards the father of a family. They heap together by night in the house chips of wood, and place on the milk-pails full of milk different sorts of animals' dung. As soon as the father of the family 


\section{The Paganism of the Ancient Prussians.}

perceives this, and, instead of scattering the chips or throwing the dung off the milk-pails, partakes of the tainted milk along with all his family, then the spirits are said to appear and remain with them.

Moreover, the Lithuanians and Samogitæ keep snakes warm under the stove, or in a corner of the steam-room where the table stands. These snakes they worship as they would a divine being; and at a regular season of the year the sacrificers summon them forth to share the meal. But they come out and climb up over a clean cloth and sit on the table. When they have there tasted the several dishes, they go down again and hide themselves in their holes. When the snakes have gone away the men gladly eat up the dishes of which they have had a first taste, and expect that for that year all things will turn out happily for them. If, however, the snakes have not come out in answer to the prayers of the sacrificer, or have refused to taste the dishes placed on the table, then they believe that in that year they will suffer some great calamity.

Besides this the same races have among them fortunetellers,' who are called in the Ruthenian tongue Burty. These, invoking the white Potrimp, pour wax into water, and according to the figures and images into which it runs, shape their predictions in regard to all matters they have been asked about. I myself knew a poor woman who had for long been awaiting the return of her absent son; for her son had left Prussia and gone to Denmark. She consulted a fortune-teller, and he told her that he had perished by shipwreck. For the wax, when poured into the water, took the form of a broken ship and the shape of a man floating flat on his back close by the ship.

Among the Samogitz there is a mountain situated by the River Nauuassa, on the top of which formerly a fire was kept perpetually alight by a priest, in honour of Pargn himself, who is still believed by superstitious people' to control thunder and tempest. So much for their sacrifices. 
Now for their marriage rites, funerals, and wakes, about which I can tell you things as laughable as they are superstitious. Among the Sudini, Curonenses, Samogitæ, and Lithuanians, girls of noble birth in places carry a bell, which is tied by a string to the girdle and hangs down to the knees. They are not led in marriage, but are carried off after the old Lacedemonian manner instituted by Lycurgus. They are, however, carried off not by the bridegroom himself, but by two of his kinsmen. And when they have been carried off, and not before, the consent of the parents is sought and the marriage contracted.

When the wedding is actually being held, the bride is led three times round the hearth, and is then placed in a chair by it. As she sits on the chair, her feet are, washed; and the water in which her feet are washed is sprinkled over the marriage bed and over all the furniture of the home. In the same way the guests, who have been invited to the wedding, are sprinkled. After that the bride's mouth is smeared over with honey and her eyes are hidden with a veil; and with her eyes thus veiled she is led to all the entrances of the house and is told to touch and beat them with her right foot. . At each entrance is scattered around wheat, siligo, oats, grain, pease, beans, and poppy. For the man who follows the bride carries a bag full of all sorts of fruits, and as he scatters them about declares that none of these shall be wanting to the bride, if she reverently follows her religion and looks after her household affairs with all due diligence. This done, the veil is taken off the bride's eyes and the feast is held.

In the evening when the bride is going to be led off to bed, in the course of the dancing her hair is cut off, and when that is done the women put a garland on her, decked with a white kerchief, which wives may wear until they have borne a son. For until then wives conduct themselves as if they were virgins.

In the end she is led into her chamber, where, after being 


\section{The Paganism of the Ancient Prussians.}

struck and beaten, she is thrown on to the bed and handed over to the bridegroom. Then, instead of wedding-cakes, are brought the testicles of a goat or of a bear, the partaking of which together on the very day of the wedding is supposed to render the wife fecund. For this reason also, no castrated animal is slain on the occasion in view of the wedding.

At funerals the following rite is observed by the country folk. The bodies of the dead are dressed up in their coats and trousers and are placed upright on a bench. Then their nearest relations sit down by the body and drink and carouse, swilling beer and raising a funeral lamentation, which in the Ruthenian tongue has the following sound:

"Hale le / le le/y procz ty mene vmarl? ii za tii nie miel szto nesty albo pity? y procz tii vmarl? Ha le le/le le ii za tii nie miel krasz iie mlodzice? ii procz tii vmarl?" That is to say: "Ah, ah me! Why hast thou died? Was there lacking to thee food or drink? Why then hast thou died? Ah, ah me! Hadst thou not a beautiful wife? Why then 'hast thou died?"

With such lamentations as this, they enumerate in order all the external blessings of the one whose death they deplore, to wit, his children, sheep, oxen, horses, geese, cocks, \&c. And as they enumerate each item they chant this refrain: "Why then hast thou died when thou hadst these?"

After the lamentation is done, presents are given to the corpse, namely, to a woman a thread and needle, to a man a linen cloth, which is folded round his neck. When the body is carried out for burial, many follow the funeral on horseback and drive chariots towards the place, whither the body is being carried. And they draw their swords and smite the winds, crying, aloud: "Sey geythe begaythe peck elle." That is: "Flee, ye demons, into hell." Those who conduct the funeral throw down coins into the grave, as, if to help the dead on his way with journey-money. They 


\section{The Paganism of the Ancient Prussians. 30I}

also place bread and a pitcher full of beer at the head of the corpse brought to the tomb, that the soul may be neither thirsty nor hungry. A wife, early and late, at sunrise and sunset, sits or lies on the tomb of her lost husband and laments for thirty days. The kinsmen, however, hold banquets on the third, sixth, ninth, and fortieth days after the interment. To these banquets they invite the soul of the deceased, praying in front of the door. In these banquets, in which they toast ${ }^{1}$ the dead, they sit in silence at a table as if they were dumb, and use no knives. At table, however, two women wait and put food before the guests and also forbear to use a knife. They each throw something from every dish under the table, upon which they believe the soul feeds, and they pour out drink for them [i.e. for the dead souls.] If perchance anything drops off the table on to the ground, they do not pick it up, but leave it to be eaten by the deserted souls-such is their phrase for such souls as have neither kinsmen nor friends living, by whom they could be entertained at the feast. When the meal is finished, the sacrificer rises from the table and clears out the house with brooms. And he casts out the souls of the dead along with the dust, as if they were fleas, and prays them in the following words to quit the house: "Iely, Pily ducisse: nu wen, nu wen." That is: "Ye have eaten and drunk, beloved souls; go ye forth, go ye forth." After that the guests begin to talk to one another and vie in their cups each with his fellow. The women drink first before the men, and the men in turn with the women, and they kiss one another.

Of this oblation of food over the tombs of the dead Augustine also makes mention in his $15^{\text {th }}$ Discourse, concerning the Saints, and his words are these :

"I wonder why among some infidels of to-day so pernicious an error has become so common, I mean of putting

1 The writer has the Latin word parentant, and uses the word parentalia to describe the whole ceremony of the wake. 
302 The Paganism of the Ancient Prussians.

together food and wine on the tombs of the dead, as if the souls come forth out of the bodies and wanted carnal food. For it is only the flesh which wants banquets and refections; but the spirit and soul do not want them. Anyone will tell you he is preparing for his dear ones what he devours himself. What benefits the belly he sets down to piety, \&c." So far Augustine.

These details about the superstitions, rites, and ceremonies of these races I relate, having witnessed some of them and having heard others from men worthy of credence. Do you, however, my most distinguished friend, as one accustomed to be delighted by a knowledge of various things, take in good part this poor essay written by one most attached to your person. 